\title{
A Comparative Study of Storage Related Haematological Changes in Whole Blood and PRBC in Blood Bank of a Tertiary Care Hospital
}

\author{
Pratibha Shirvastava ${ }^{\circledR 1}$, Shyamoli Dutta ${ }^{\circledR 2}$ \\ ${ }^{1}$ Post Graduate Student, Department of Pathology, Teerthankar Mahaveer Medical College, TMU,, Moradabad, Uttar Pradesh, India, ${ }^{2}$ Professor, Department of \\ Pathology, Teerthankar Mahaveer Medical College, TMU, Moradabad, Uttar Pradesh, India.
}

\section{Abstract}

Background: Blood transfusion is very common in present era. Now day's whole blood transfusion is common but also the blood product like red blood cell, white blood cell, platelets, clotting factor, plasma can be done the aim of study to know the storage related changes in whole blood, packed red blood cell. Subjects and Methods: In our institution we have selected 100 voluntary blood donors sample in blood bank of Teerthankar Mahaveer medical college and research centre, Moradabad up to 12 month. Results: The store blood is Followed up to 35th days during regular interval $1^{s t}, 7^{t h}, 14^{t h}, 21^{s t}, 28^{t h}$ and $35^{t h}$ day, in the blood there is significant change in and all other component in all sample. Conclusion: In the case of storage of blood in blood bank. As the number day of store is more the haematological changes is more significant.

Keywords: RBC, Blood, WBC

Corresponding Author: Shyamoli Dutta, Professor, Department of Pathology, Teerthankar Mahaveer Medical College, TMU, Moradabad, Uttar Pradesh, India.

E-mail: pratibhashrivastava02@gmail.com

Received: 16 May 2020

Revised: 23 June 2020

Accepted: 3 July 2020

Published: 9 July 2020

\section{Introduction}

Blood is a body fluid in humans and other animals that delivers necessary substances such as nutrients and oxygen to the cells and transports metabolic waste products away from those same cells. ${ }^{[1]}$

The blood cells are mainly red blood cells (also called RBCs or erythrocytes), white blood cells (also called WBCs or leukocytes) and platelets (also called thrombocytes). The most abundant cells in vertebrate blood are red blood cells. These contain haemoglobin, an iron-containing protein, which facilitates oxygen transport by reversibly binding to this respiratory gas and greatly increasing its solubility in blood. In contrast, carbon dioxide is mostly transported extracellular as bicarbonate ion transported in plasma. ${ }^{[2]}$

Blood transfusion is the process of receiving blood or blood products into circulatory system intravenously. Transfusions are used for various medical conditions to replace lost components of the blood. In early day, transfusions used whole blood, but nowadays transfusion of whole blood as wells as components of the blood, such as red blood cells, white blood cells, plasma, clotting factors, and platelets can be done individually.
The most common form of obtaining blood is from voluntary blood donation. A blood donation occurs when a person voluntarily has blood drawn and used for transfusions and/or made into biopharmaceutical medications by a process called fractionation (separation of whole-blood components). Donation may be of whole blood, or of specific components directly by apheresis. Blood banks often participate in the collection process as well as the procedures that follow it.

Storage of blood is governed by the regulatory body. In India it is Central Drugs Standard Control Organization (CDSCO) which is headed by the Drugs Controller General (India). The Drugs and Cosmetics Act, 1940 identify clearly about accommodation, manpower, equipment, supplies and reagents and good manufacturing practices. Licensing and monitoring of the blood bank is responsibility of Drug Controller General of India. [3]

The first anticoagulant preservative was introduced by Rous and Turner in 1916. Rous Turner's solution as used for storage of human blood during the First World War. ${ }^{[4]}$ Loutit and Mollison of Great Britain developed the first anticoagulant of the modern era, known as acid-citrate-dextrose (ACD). ACD extended the shelf life of refrigerated blood to 21 days, and ACD remained in wide spread usage until the 1960s, when it 
was replaced by citrate-phosphate-dextrose (CPD) and citratephosphate-dextrose-adenine (CPDA) solutions that increased shelf life to 35 days and 42 days respectively. More recently, additive solutions containing saline, adenine, and dextrose have been developed to augment red cell survival following transfusion, although without any direct increase in storage duration. ${ }^{[5]}$

The collected blood is stored in plastic bag made of PVC with citrate phosphate dextrose adenine (CPDA-1) an anticoagulant solution, containing citric acid, sodiumcitrate, mono basic sodium phosphate, dextrose, and adenine, used for the preservation of whole blood and red blood cells for up to 42 days; it extends red cellsurvival by providing adenine needed for the maintenance of red cell ATP levels.

The various changes that occur within both the RBC and storage media during ex vivo preservation have been collectively termed the RBC "storage lesion" These alterations can be extensive and are primarily classified into three broad categories: biochemical, biomechanical, and immunologic. Importantly, the alterations that occur during this storage process are believed responsible for many of the increasingly recognized adverse effects associated with RBC transfusion. ${ }^{[6]}$

The goal of blood preservation is to provide viable and functional blood components for patients requiring blood transfusion. More than $70 \%$ of red cells should remain viable in circulation 24hours after transfusion of stored blood in CPDA- 1 for 35 days. The blood is stored at $2-6^{\circ} \mathrm{C}$ to maintain the optimal viability. The loss of red cells viability is correlated with the "lesion of storage" due to various biochemical changes:

- Decrease in $\mathrm{pH}$

- Build up of lactic acid

- Decrease in glucose consumption

- Decrease in ATP level

- Low 2,3-DPG levels

Storage of blood for long period of time leads to changes in blood biochemistry. Prolonged contact of plasma with RBCs results in exchange of contents between plasma and red cells which leads to changes in concentrations of analyteas well as dilution of the blood. If not stored under proper condition, some RBC's may undergo spontaneous haemolysis while in storage. Other blood components tend to lose the ability to survive in the recipient's circulation following transfusion. In spite of storing blood with CPDA, the storage time has a negative impact on the biochemical composition on whole blood as well as other components. ${ }^{[7]}$

As stored blood ages, intraerythrocytic energy sources are depleted resulting in reduced structural integrity of the membrane. Thus, stored red cells become less deformable and more fragile as they age. This fragility leads to release of cell-free haemoglobin and formation of micro particles, submicron haemoglobin-containing vesicles. Upon transfusion, it is likely that additional haemolysis and micro particle formation occurs due to breakdown of fragile red blood cells. Release of cell-free haemoglobin and micro particles leads to increased consumption of nitric oxide (NO), an important signalling molecule that modulates blood flow, and may promote inflammation. Stored blood may also be deficient in recently discovered blood nitric oxide synthase activity. ${ }^{[8]}$

Transfusions of RBC containing increased levels of potassium have been related with myocardial hyperkalemia and neonatal arrhythmia. Storage damages are manifested by the alteration in cell flexibility and reduction in glucose, diphosphoglycerate and adenosine triphosphate content, as well as acidosis takes place as a result of lactic acid accumulation. The sodium/potassium ATPase pump is deactivated causing a decrease in sodium with an increase in potassium levels in plasma.

The most common changes in the biochemical structure of the red blood cells occur due to anaerobic glycolysis and are relative to the storage period. Furthermore, stored erythrocytes have tendency to lysisthattriggers the formation of haemoglobin containing microvesicles and the release of free hemoglobin which may add to transfusion side effects. ${ }^{[9]}$

The epidemiologic studies are confounded by a general tendency to transfuse sicker patients. Several larger human randomized controlled trials have shown no effect of transfusing longer-stored RBCs. ${ }^{[10]}$

There is limited number of studies in India about changes in stored blood in blood banks. Therefore a need for a study was seen especially at tertiary level where blood is collected, stored as well as dispensed.

This study has been undertaken in a tertiary medical centre to assess the storage related changes as well as comparison of changes between PRBC and Whole blood.

\section{Aim and Objectives}

The present study was conducted in the Department of Pathology, Teerthankar Mahaveer Medical College \& Research Centre, Moradabad with the objectives:

- To study the storage related changes in whole blood and packed RBC

- To compare haematological changes between whole blood and packed $\mathrm{RBC}$ on storage

\section{Subjects and Methods}

\section{Study Design}

- Purposive Observational Study 


\section{Duration of Study}

- 12 months (January 2018 to December 2018)

\section{Study Population}

- Voluntary blood donors in blood bank of Teerthankar Mahaveer Medical College \& Research Centre, Moradabad.

\section{Sample Size Estimation}

- Sample size was calculated on the basis of maximum variation in change of $\mathrm{CBC}$ parameters within the follow up period using the formula for comparison of means discussed in 'A. Indrayan, Basic Methods of Medical Research.

- Considering $95 \%$ confidence level, $90 \%$ power of study and $20 \%$ loss to follow up the sample size was calculated to be 95 which were taken as 100 after rounding off.

\section{Inclusion criteria}

- Healthy blood donors who were accepted for donation after considering deferral criteria in blood bank.

\section{Exclusion criteria}

- Clotted blood samples

- Blood bags found to be positive for transfusion transmitted infection testing.

\section{Specimen Collection}

Age and related demographic information was collected from donor form.

After drawing blood from healthy blood donor into citrate phosphate dextrose adenine (CPDA-1) blood bag, it is stored in refrigerator at $4 \pm 2{ }^{\circ} \mathrm{C}$.

Complete blood count (CBC) was measured on all sample at the time of blood collection and at 7, 14,21, 28 and 35 days of storage.

A complete blood count (CBC) is a blood test used to evaluate the overall health of subjects and detect a wide range of disorders, including anemia, infection and leukemia. A complete blood count test measures several components such as $\mathrm{CBC}$ was performed on automated hematologyanalyzer in central clinical laboratory.

\section{Parameters for assessment}

Demographic Parameters includes Age, Gender, Religion and Blood Group of donor Complete blood count, which includes:

WBC, Lymphocytes, Granules, MID, RBC, Hb, HCT, MCV, MCHC, MCH, RDW\%, RDWA FL, Platelet, MPV FL, PDW FL, PCT \%, LPCR \% \& ESR.

\section{Data / Statistical Analysis}

Data entry was made in MS Office Excel software in codes and analysis was done by SPSS software ${ }^{\circledR}$ version 18.0. Descriptive statistical analysis, which included frequency and percentages, was used to characterize the data. Student's $t$ test was applied to check significance of changes. $p<0.05$ was considered statistically significant. A confidence interval (CI) is a type of interval estimate, computed from the statistics of the observed data that might contain the true value of an unknown population parameter. A $95 \%$ confidence interval is a range of values that we can be $95 \%$ certain contains the true mean of the population.

\section{Results}

Among the study subjects $98 \%$ were males and $2 \%$ were females. Hindus were 52\%, Muslims were $43 \%$ and rest $5 \%$ were Sikhs. The blood samples involved $2 \% \mathrm{~A}-\mathrm{ve}, 20 \% \mathrm{~A}$ $+v e, 9 \% \mathrm{AB}+\mathrm{ve}, 2 \% \mathrm{~B}-\mathrm{ve}, 33 \% \mathrm{~B}+\mathrm{ve}$, and $2 \% \mathrm{O}-\mathrm{ve}$ and $32 \% \mathrm{O}+$ ve.

The mean WBC count at $1^{\text {st }}$ day was $5.18 \pm 0.15\left(\mathrm{x} 10^{9} / \mathrm{L}\right)$ which after fluctuations finally at $35^{\text {th }}$ day had the reduced value $2.79 \pm 0.14\left(\times 10^{9} / \mathrm{L}\right)$. The changes in $\mathrm{WBC}$ count from baseline ( $1^{\text {st }}$ day) at each week of follow-up was found to be highly significant $(\mathrm{p}<0.001)$

The mean LYM count at $1^{\text {st }}$ day was $3.18 \pm 0.06\left(\mathrm{x} 10^{9} / \mathrm{L}\right)$ which after fluctuations finally at $35^{t h}$ day had the reduced value $2.53 \pm 0.15\left(\times 10^{9} / \mathrm{L}\right)$. The changes in LYM count from baseline ( $1^{\text {st }}$ day) at each week of follow-up was found to be highly significant $(\mathrm{p}<0.001)$ the mean LYM\% at $1^{\text {st }}$ day was $61.66 \pm 2.64 \%$ which after fluctuations finally at $35^{\text {th }}$ day had the increased value $84.40 \pm 0.14 \%$. The changes in LYM\% from baseline ( $1^{\text {st }}$ day) at each week of follow-up was found to be highly significant $(\mathrm{p}<0.001)$.The mean GRAN $\left(\times 10^{9} / \mathrm{L}\right)$ at $1^{\text {st }}$ day was $1.53 \pm 0.22$ which after fluctuations finally at $35^{\text {th }}$ day had the reduced value $0.34 \pm 0.15$. The changes in GRAN from baseline ( $1^{\text {st }}$ day) at each week of follow-up was found to be highly significant $(\mathrm{p}<0.001)$ the mean GRAN\% at $1^{\text {st }}$ day was $28.33 \pm 4.18$ which after fluctuations finally at $35^{\text {th }}$ day had the reduced value $5.20 \pm 0.17$. The changes in GRAN from baseline ( $1^{\text {st }}$ day) at each week of follow-up was found to be highly significant $(\mathrm{p}<0.001)$

The mean MID at $1^{\text {st }}$ day was $0.46 \pm 0.02\left(\mathrm{x} 10^{9} / \mathrm{L}\right)$ which after fluctuations finally at $35^{t h}$ day had the increased value $0.55 \pm 0.15\left(\times 10^{9} / \mathrm{L}\right)$. The changes in MID from baseline $\left(1^{\text {st }}\right.$ day) at each week of follow-up was found to be highly significant $(\mathrm{p}<0.001)$ the mean MID $\%$ at $1^{\text {st }}$ day was $8.05 \pm 0.50$ which after fluctuations finally at $35^{\text {th }}$ day had the increased value $9.37 \pm 0.15$. The changes in MID\% from baseline ( $1^{\text {st }}$ day) at each week of follow-up was found to be highly significant $(\mathrm{p}<0.001)$ except at $14^{\text {th }}$ day where the difference was insignificant $(\mathrm{p}=0.083)$

The mean RBC count at $1^{\text {st }}$ day was $4.10 \pm 0.01\left(\mathrm{x} 10^{12} / \mathrm{L}\right)$ which after fluctuations finally at $35^{\text {th }}$ day had the increased value $7.38 \pm 0.14\left(\times 10^{12} / \mathrm{L}\right)$. The changes in $\mathrm{RBC}$ count from 


\begin{tabular}{|c|c|c|c|c|c|c|}
\hline \multirow[t]{2}{*}{ WBC $\left(\times 10^{9} / \mathrm{L}\right)$} & \multicolumn{2}{|c|}{ Value at the Time } & \multicolumn{2}{|c|}{ Diff from BL (1st day) } & \multicolumn{2}{|c|}{ Significance } \\
\hline & Mean & SD & Mean Diff. & SD of Diff. & t-value & p-value \\
\hline 1st Day & 5.18 & 0.15 & - & - & - & - \\
\hline 7th Day & 4.13 & 0.12 & 1.04 & 0.18 & 58.49 & $<0.001$ \\
\hline 14th Day & 3.26 & 0.13 & 1.91 & 0.20 & 97.63 & $<0.001$ \\
\hline 21st Day & 2.67 & 0.02 & 2.51 & 0.15 & 167.11 & $<0.001$ \\
\hline 28th Day & 2.72 & 0.03 & 2.46 & 0.15 & 162.54 & $<0.001$ \\
\hline 35th Day & 2.79 & 0.14 & 2.39 & 0.21 & 113.28 & $<0.001$ \\
\hline
\end{tabular}

\section{Table 2: Storage Related Changes in RBC}

\begin{tabular}{lllllll}
\hline RBC $\left(\times 10^{12} / \mathrm{L}\right)$ & \multicolumn{2}{l}{ Value at the Time } & \multicolumn{2}{l}{ Diff from BL (1st day) } & \multicolumn{2}{l}{ Significance } \\
& Mean & SD & Mean Diff. & SD of Diff. & t-value & p-value \\
1st Day & 4.10 & 0.01 & - & - & - & - \\
7th Day & 5.12 & 0.56 & -1.03 & 0.56 & -18.40 & $<0.001$ \\
14th Day & 7.95 & 0.15 & -3.85 & 0.15 & -261.27 & $<0.001$ \\
21st Day & 7.66 & 0.26 & -3.57 & 0.26 & -139.11 & $<0.001$ \\
28th Day & 8.51 & 0.26 & -4.41 & 0.26 & -168.12 & $<0.001$ \\
35th Day & 7.38 & 0.14 & -3.28 & 0.14 & -240.10 & $<0.001$ \\
\hline
\end{tabular}

Table 3: Storage Related Changes in HGB

\begin{tabular}{cllllll}
\hline HGB g/dl & \multicolumn{2}{l}{ Value at the Time } & \multicolumn{2}{l}{ Diff from BL (1st day) } & \multicolumn{2}{l}{ Significance } \\
& Mean & SD & Mean Diff. & SD of Diff. & t-value & p-value \\
1st Day & 11.91 & 0.04 & - & - & - & - \\
7th Day & 12.05 & 0.05 & -0.14 & 0.06 & -23.57 & $<0.001$ \\
14th Day & 11.90 & 0.04 & 0.01 & 0.06 & 2.07 & $<0.001$ \\
21st Day & 12.12 & 0.00 & -0.21 & 0.04 & -48.58 & $<0.001$ \\
28th Day & 12.13 & 0.01 & -0.22 & 0.04 & -52.06 & $<0.001$ \\
35th Day & 12.36 & 0.15 & -0.45 & 0.16 & -27.59 & $<0.001$ \\
\hline
\end{tabular}

baseline ( $1^{\text {st }}$ day) at each week of follow-up was found to be highly significant $(\mathrm{p}<0.001)$.

The mean HGB at $1^{\text {st }}$ day was $11.91 \pm 0.04 \mathrm{~g} / \mathrm{dl}$ which after fluctuations finally at $35^{\text {th }}$ day had the increased value $12.36 \pm 0.15 \mathrm{~g} / \mathrm{dl}$. The changes in HGB count from baseline ( $1^{\text {st }}$ day) at each week of follow-up was found to be highly significant $(\mathrm{p}<0.001)$. The mean HCT\% at $1^{\text {st }}$ day was $35.18 \pm 0.97$ which after fluctuations finally at $35^{\text {th }}$ day had the reduced value $34.34 \pm 0.15$. The changes in $\mathrm{HCT} \%$ from baseline ( $1^{\text {st }}$ day) at each week of follow-up was found to be highly significant $(\mathrm{p}<0.001)$. The mean MCV F1 at $1^{\text {st }}$ day was $79.21 \pm 0.85$ which after fluctuations finally at $35^{\text {th }}$ day had the reduced value $77.27 \pm 0.15$. The changes in MCV F1 from baseline ( $1^{\text {st }}$ day) at each week of follow-up was found to be highly significant $(\mathrm{p}<0.001)$.
The mean MCHC at $1^{\text {st }}$ day was $35.19 \pm 0.04 \mathrm{~g} / \mathrm{dl}$ which after fluctuations finally at $35^{\text {th }}$ day had the increased value $35.52 \pm 0.13 \mathrm{~g} / \mathrm{dl}$. The changes in MCHC from baseline $\left(1^{\text {st }}\right.$ day) at each week of follow-up was found to be highly significant $(\mathrm{p}<0.001)$.

The mean $\mathrm{MCH}$ at $1^{\text {st }}$ day was $29.00 \pm 0.10 \mathrm{pg} / \mathrm{dl}$ which after fluctuations finally at $35^{\text {th }}$ day had the increased value $29.38 \pm 0.16 \mathrm{pg} / \mathrm{dl}$. The changes in $\mathrm{MCH}$ from baseline $\left(1^{\text {st }}\right.$ day) at each week of follow-up was found to be highly significant $(\mathrm{p}<0.001)$.

The mean RDW\% at $1^{\text {st }}$ day was $13.61 \pm 0.16$ which after fluctuations finally at $35^{\text {th }}$ day had the increased value $15.22 \pm 0.14$. The changes in RDW\% from baseline ( $1^{\text {st }}$ day) at each week of follow-up was found to be highly significant 


\begin{tabular}{|c|c|c|c|c|c|c|}
\hline \multirow[t]{2}{*}{$\mathrm{MCH}$ pg } & \multicolumn{2}{|c|}{ Value at the Time } & \multicolumn{2}{|c|}{ Diff from BL (1st day) } & \multicolumn{2}{|c|}{ Significance } \\
\hline & Mean & SD & Mean Diff. & SD of Diff. & t-value & p-value \\
\hline 1st Day & 29.00 & 0.10 & - & - & - & - \\
\hline 7th Day & 28.64 & 0.10 & 0.36 & 0.15 & 24.07 & $<0.001$ \\
\hline 14th Day & 29.11 & 0.02 & -0.11 & 0.10 & -10.63 & $<0.001$ \\
\hline 21st Day & 29.07 & 0.03 & -0.07 & 0.11 & -6.68 & $<0.001$ \\
\hline 28th Day & 29.21 & 0.02 & -0.20 & 0.10 & -19.73 & $<0.001$ \\
\hline 35th Day & 29.38 & 0.16 & -0.37 & 0.18 & -20.62 & $<0.001$ \\
\hline
\end{tabular}

$(\mathrm{p}<0.001)$. The mean RDWA FL at $1^{\text {st }}$ day was $65.10 \pm 0.42$ which after fluctuations finally at $35^{\text {th }}$ day had the increased value $66.40 \pm 0.15$. The changes in RDWA FL from baseline $\left(1^{s t}\right.$ day) at each week of follow-up was found to be highly significant $(\mathrm{p}<0.001)$.

The mean PLT at $1^{\text {st }}$ day was $112.90 \pm 0.12\left(\times 10^{4} / \mathrm{L}\right)$ which after fluctuations finally at $35^{\text {th }}$ day had the reduced value $88.76 \pm 0.14\left(\times 10^{4} / \mathrm{L}\right)$. The changes in PLT from baseline $\left(1^{s t}\right.$ day) at each week of follow-up was found to be highly significant $(\mathrm{p}<0.001)$. The mean MPV FL at $1^{\text {st }}$ day was $7.86 \pm 0.07$ which after fluctuations finally at $35^{t h}$ day had the reduced value $8.67 \pm 0.15$. The changes in MPV FL from baseline ( $1^{\text {st }}$ day) at each week of follow-up was found to be highly significant $(\mathrm{p}<0.001)$. The mean PDW FL at $1^{\text {st }}$ day was $10.54 \pm 0.08$ which after fluctuations finally at $35^{\text {th }}$ day had the increased value $12.27 \pm 0.14$. The changes in PDW FL from baseline ( $\left(1^{\text {st }}\right.$ day) at each week of follow-up was found to be highly significant $(\mathrm{p}<0.001)$. The mean PCT $\%$ at $1^{\text {st }}$ day was $0.11 \pm 0.02$ which after fluctuations finally at $35^{\text {th }}$ day had the increased value $0.37 \pm 0.15$. The changes in PCT\% from baseline ( $1^{\text {st }}$ day) at each week of follow-up was found to be highly significant $(\mathrm{p}<0.001)$. The mean LPCR $\%$ at $1^{\text {st }}$ day was $16.69 \pm 0.35$ which after fluctuations finally at $35^{\text {th }}$ day had the increased value $20.85 \pm 0.14$. The changes in LPCR\% from baseline ( $1^{\text {st }}$ day) at each week of follow-up was found to be highly significant $(\mathrm{p}<0.001)$.

\section{Discussion}

It was not possible to include all the characteristics in one study. On the basis of the review of the literature some important characteristics were identified and findings have been explaining and discussing with other important and directly relevant issues describing in this chapter. In the light of the objectives of the present study, this paper is devoted to deals with explaining the results, interpretation of data, compares it with other research, opinion etc. with very clearly and fully stating, supporting, explaining and discussing other important and directly relevant issues and describing the patterns principles and relationships shown by each finding result and putting them in perspective.

Previous studies found deleterious storage effect on blood cell morphology and functions. ${ }^{[11]}$ This study found similar trend of storage lesion in whole blood storage. There are limited numbers of studies in India about changes in stored blood in blood banks. The present study was deliberated with a purpose to assess the storage related changes as well as comparison of changes between PRBC and Whole blood. ${ }^{[12-14]}$

\section{Distribution with respect to gender and blood groups}

Present study comprised with $98 \%$ was males and $2 \%$ were females blood samples. In which blood samples involved $2 \%$ $\mathrm{A}-\mathrm{ve}, 20 \% \mathrm{~A}+\mathrm{ve}, 9 \% \mathrm{AB}+\mathrm{ve}, 2 \% \mathrm{~B}-\mathrm{ve}, 33 \% \mathrm{~B}+\mathrm{ve}$, and $2 \%$ $\mathrm{O}-\mathrm{ve}$ and $32 \% \mathrm{O}+\mathrm{ve}$. Considering that Chabbra $\mathrm{S}$ et al (2017) included eligible donors for blood donation belonged to 18-25 age group (47\%) followed age group of 26-30 years (23\%). ${ }^{[15]}$ Only 2 of the donors were female. While study conducted by Verma $\mathrm{M}$ et al (2015) in 30 donors 25 were males and 5 were females. ${ }^{[7]}$ The ages ranged between $21-40$ years (mean age 24.2 years). In addition, the donors were 10 in number; they had their ages ranging from 23 to 28 years (mean age 25.2 yrs) with corresponding blood groups of 1A-, 1A-, 2B+, 5O+ and 1O-. (30) Even though according to Enoch aninagyei et al 2018 , they limited their study not take into consideration the blood group and gender. ${ }^{[13]}$

\section{Storage Related Changes in WBC}

There is substantial evidence from in vitro studies documenting the change that hematological parameters undergo during storage. When changes observed in the hematological parameters were categorized based on whether the initial days mean values were maintained when compared with other days, normal or high some of the hematological parameters analyzed decreased or increased.

In the present study mean WBC count reduces significantly from 1st day to 35th day. Decreasing WBC counts observed during the present study are in agreement with findings by Jobes et al who investigated the characterization of coagulation properties in refrigerated whole blood for transfusion in an invitro study. ${ }^{[12]}$ 
A study recorded similar finding that significant changes in total white blood cell. There was consecutive reduction in total white blood cell. ${ }^{[13]}$ Moreover, according to cohl et al (1981), when the mean values of WBC on day 1 was compared to day 7 , it was observed that there was rapid deterioration in granulates WBC. These changes in white blood cells are most likely due to the sum effects of the loss of individual cell characteristics specifically degeneration that is known to occur as the cell ages. ${ }^{[14]}$

On comparison of day 0 versus other days stated interval, it was disclosed that there is change in shape of RBC from disc to echinocytes and spherical, i.e. poikilocytosis increases with storage. Also changes in WBC and platelet occur with storage. ${ }^{[15]}$

\section{Storage Related Changes in RBC}

Preservation and long term storage of Red Blood Cells (RBCs) is needed to ensure a readily available, safe blood supply for transfusion medicine. Storage has a negative effect on $\mathrm{RBC}$ oxygen delivery and emerging evidence suggests that allogenic $\mathrm{RBC}$ infusion may actually harm some recipients. Also RBC storage lesions include decreased RBC stability, alterations in various metabolites and the metabolic status of the cell. Although, present study showed increment of mean $\mathrm{RBC}$ count from 1st day was to 35th day.

Moreover, García-Roa M et al (2017) added that Red blood cell storage time and transfusion, found that due to storage, morphological changes, accumulation of lactic acid and potassium/calcium, a decrease in 2,3-DPG and ATP, decrease in $\mathrm{pH}$ and glycolysis rate. Another study performed to assess "Changes in RBC and Platelet indices in CPDA stored Blood." Reported that the non-significant changes in $\mathrm{RBC}$ indices on long storage. ${ }^{[16]}$

\section{Effect of Storage on lymphocytes and granulocytes}

Gupta P et al (2016) reported that no change in lymphocytes is seen. ${ }^{[15]}$ Whereas in present study the mean lymphocytes count at decreases from first day to thirty fifth day. Although, percentage of lymphocytes increases. The changes in lymphocytes count from baseline at each week of follow-up were found to be highly significant.

A Study showed that differential leucocyte count by automated haematology analyzer, there is decrease in granulocyte percentage with increase in lymphocyte percentage, while there is no significant change in MID percentage. ${ }^{[17]}$ Whereas in the present study the mean MID increased from 1st day to 35th day. The changes in MID from baseline at each week of follow-up was found to be highly significant.

\section{Consequence of Storage on other haematological parame- ters}

A study determined haematological parameters weekly for 5 weeks whilst plasma haemoglobin, $\%$ haemolysis, plasma electrolytes and LDH were measured at the end of week 1, week 3 and week 5 . There were consecutive reductions of RBC count, haemoglobin level, and HCT in all successive weekly estimations compared to baseline values. ${ }^{[13]}$ While present study showed increased mean haemoglobin from $1^{\text {st }}$ day to $35^{t h}$. In addition, Chabbra $S$ et al (2017) observed in their study that statistically non-significant changes were observed in $\mathrm{Hb}(13.061 \mathrm{~g} / \mathrm{dl}$ on day 1 and $12.988 \mathrm{~g} / \mathrm{dl}$ on day 28. ${ }^{[15]}$ Another study also showed non-significant changes were observed in $\mathrm{Hb}, \mathrm{PCV}$ and other hematological parameters throughout the study. ${ }^{[15]}$

The changes in HCT\% reduced from baseline (1st day) at each week of follow-up was found to be highly significant $(p<0.001)$. Whilst Chabbra $S$ et al (2017) observed that statistically non-significant changes were observed in HCT (40.184\% on day 1 and $43.466 \%$ on day 28$).{ }^{[18]}$

A study concluded that no significant changes were observed in MCV throughout the study. However, in present study changes in MCV F1 from baseline at each week of follow-up was found to be highly significant, whereas the mean MCHC increased from 1st day to 35th day. Chabbra S et al (2017) observed in their study that was statistically non-significant changes were observed in MCHC (32.549 on day 1 and 29.559 on day 28) and MCH (29 on 325 on day 1 and 28.803 day 28). ${ }^{[18]}$ This contradicts the present study that the changes in $\mathrm{MCH}$ from baseline at each week of follow-up was found to be highly significant.

A progressive increase in RDW was also noticed by Adias TC et al 2012 after comparison of the mean cell value increased from day 1 and 14 consistent consequence found in present study and this agrees with the study of Cohl et al Similar finding reported in Enoch Aninagyei et al 2018 that RDW$\mathrm{CV} \%$ values consecutively increased in all donor groups with respect to successive weekly measurement. ${ }^{[13,14]}$

The collection, processing and storage of platelets for clinical use have undergone significant changes over the last few decades and novel approaches are being investigated to develop improved platelets products on new anticoagulant and additive solutions, modified storage containers and collection sets, procedures for virus and bacterial inactivation, chemical and physical methods to maintain the shelf life in development of artificial or pseudo artificial platelet products. ${ }^{[12,14]}$

MPV and LPCR showed drastic increase from day 14 down to day 28 and found that MPV initially increased steadily, reaching a maximum mean percent change on day 5 , and on day 6 and 7, the mean percentage change had drastically increased according to Adias TC et al 2012. While in present study the mean MPV FL reduced and mean LPCR\% increases from first day to thirty fifth days. This agrees with the work done by Cohl et al. ${ }^{[14]}$ 
The results reported herein have significant implications and require focus of much research attention. Persons, who work at the transfusion centers, suggest an urgent need for the introduction of policies for safe transfusion practices and education among blood donors and staff members at the centers.

\section{Conclusion}

As blood has tendency to clot and improper storage can lead to haemolysis, care has to be taken in storage of blood and its components. There is limited number of studies in India about changes in stored blood in blood banks. There fore a need for a study was seen especially at tertiary level where blood is collected, stored as well as dispensed.

\section{References}

1. Abbaspour N, Hurrell R, Kelishadi R. Review on iron and its importance for human health. J Res Med Sci. 2014;19(2):164174.

2. Dash RK, Bassingthwaighte JB. Simultaneous Blood-Tissue Exchange of Oxygen, Carbon Dioxide, Bicarbonate, and Hydrogen Ion. Ann Biomed Eng. 2006;34(7):1129-1148. Available from: https://dx.doi.org/10.1007/s10439-005-90664.

3. Amendments to Indian Drugs and Cosmetics Act and Rules Pertaining to Blood Banks in Armed Forces. Med J Armed Forces India. 2005;61(3):264-66. Available from: https://dx. doi.org/10.1016/S0377-1237(05)80170-4.

4. Macpherson WG, Bowlby AA, Wallace C, English C. History of the Great War Based on Official Documents. Can Med Assoc J. 1925;15(1):114-18.

5. Vandromme MJ, McGwin G, Weinberg JA. Blood transfusion in the critically ill: does storage age matter? Scand J Trauma Resusc Emerg Med. 2009;17:35-39. Available from: https: //dx.doi.org/10.1186/1757-7241-17-35.

6. Kor DJ, Buskirk CMV, Gajic O. Red Blood Cell Storage Lesion. Bosnian J Basic Medl Sci. 2009;9(1):S21-S27. Available from: https://dx.doi.org/10.17305/bjbms.2009.2750.

7. Oyet C, Okongo B, Onyuthi RA, Muwanguzi E. Biochemical changes in stored donor units: implications on the efficacy of blood transfusion. J Blood Med. 2018;9:111-15. Available from: https://dx.doi.org/10.2147/JBM.S163651.

8. Kim-Shapiro DB, Lee J, Gladwin MT. Storage lesion: role of red blood cell breakdown. Transfusion. 2011;51(4):844851. Available from: https://dx.doi.org/10.1111/j.1537-2995. 2011.03100.x.

9. Zimrin AB, Hess JR. Current issues relating to the transfusion of stored red blood cells. Vox Sanguinis. 2009;96:93-103. Available from: https://dx.doi.org/10.1111/j.1423-0410.2008. 01117.x.
10. Dhabangi A, Ainomugisha B, Cserti-Gazdewich C, Ddungu H, Kyeyune D, Musisi E, et al. Effect of Transfusion of Red Blood Cells With Longer vs Shorter Storage Duration on Elevated Blood Lactate Levels in Children With Severe Anemia. JAMA. 2015;314:2514-2514. Available from: https://dx.doi.org/10. 1001/jama.2015.13977.

11. Koch CG, Duncan AI, Figueroa P, Dai L, Sessler DI, Frank SM, et al. Real Age: Red Blood Cell Aging During Storage. Ann Thoracic Surg. 2019;107(3):973-980. Available from: https://dx.doi.org/10.1016/j.athoracsur.2018.08.073.

12. Jobes D, Wolfe Y, O’Neill D, Calder J, Jones L, Sesok-Pizzini $\mathrm{D}$, et al. Toward a definition of "fresh" whole blood: an in vitro characterization of coagulation properties in refrigerated whole blood for transfusion. Transfusion. 2011;51(1):43-51. Available from: https://dx.doi.org/10.1111/j.1537-2995.2010. 02772.x.

13. Aninagyei E, Doku ET, Adu P, Egyir-Yawson A, Acheampong DO. Storage related haematological and biochemical changes in Plasmodium falciparum infected and sickle cell trait donor blood. BMC Hematol. 2018;18(1):30-36. Available from: https://dx.doi.org/10.1186/s12878-018-0128-x.

14. Cohl SD, Saleem A, Makkaouide. Effects of storage of blood on stabilityof hematologic parameters. Am J Clin Pathol. 1981;76:67-69.

15. Gupta P, Goyal R, Pantola C, Amit S. To study the morphological changes seen in stored blood in a blood bank. J Evolution Med Dent Sci. 2016;5(77):5705-5709. Available from: https://dx.doi.org/10.14260/jemds/2016/1287.

16. Garcia-Roa M, Vicente-Ayuso C, Bobes M, M A. Red blood cell storage time and transfusion: current practice, concerns and future perspectives. Blood Transfusion. 2017;15(3):222-231.

17. Adias TC, Moore B. Storage Related Haematological and Biochemical Changes of CPDA-1 Whole Blood in a Resource Limited Setting. J Blood Disord Transf. 2012;3(3):124 124. Available from: https://dx.doi.org/10.4172/2155-9864. 1000124.

18. Chhabra S, Chaudhary S, Sehga PK, Singh S, Gupta M, Sen R. Changes in RBC and Platelet indices in CPDA stored Blood. Int J Healthcare Biomed Res. 2017;p. 69-75.

Copyright: (C) the author(s), 2020. It is an open-access article distributed under the terms of the Creative Commons Attribution License (CC BY 4.0), which permits authors to retain ownership of the copyright for their content, and allow anyone to download, reuse, reprint, modify, distribute and/or copy the content as long as the original authors and source are cited.

How to cite this article: Shirvastava P, Dutta S. A Comparative Study of Storage Related Haematological Changes in Whole Blood and PRBC in Blood Bank of a Tertiary Care Hospital. Asian J. Med. Res. 2020;9(2):1-7.

DOI: dx.doi.org/10.47009/ajmr.2020.9.2.PT1

Source of Support: Nil, Conflict of Interest: None declared. 